ADVANCES IN

PSYCHIATRY \& NEUROLOGY

PostįPY

Psychiatrii i Neurologii
Correspondence to/Adres do korespondencji:

Michał K. Ring

Regional Psychiatric Hospital Drewnica

1 Rychlińskiego St.

05-091 Ząbki, Poland

e-mail: michalring@gmail.com

Submitted/Otrzymano: 30.06.2021

Accepted/Przyjęto do druku: 08.09.2021

\section{Somatic comorbidities of inpatients receiving treatment for alcohol withdrawal syndrome on a psychiatric ward and their relation to delirium tremens}

\author{
Współchorobowość somałyczna \\ pacjentów leczonych z powodu \\ alkoholowego zespołu \\ abstynencyjnego w szpitalu \\ psychiatrycznym i jej związek \\ z rozwojem majaczenia alkoholowego
}

\begin{abstract}
Purpose: This study aimed to assess the influence of somatic diseases and patient characteristics (age, gender) in relation to delirium tremens (DT) episodes in alcohol withdrawal syndrome (AWS). We also analysed the influence of age, gender and specific somatic diseases on the duration of hospital stay and the frequency of comorbid somatic diseases among AWS and DT patients.

Methods: The medical records of patients admitted to an AWS treatment ward in a Polish psychiatric hospital in 2019 were analysed. In total, 800 hospitalisations of 656 patients (625 hospitalisations for AWS and 175 for DT) were evaluated.

Results: The most frequent group of somatic diseases among AWS and DT patients was cardiovascular diseases, with essential hypertension as the main medical condition. Patients suffering from DT were diagnosed with respiratory system diseases $(p<0.001)$ and pneumonia $(p<0.000)$ more often than AWS patients. Hospital stays were longer for patients with pneumonia, chronic obstructive pulmonary disease and duodenal ulcers. Patients with acute pancreatitis were hospitalised for a significantly shorter period of time than other patients. Patient gender and age did not significantly affect the development of DT. However, age was positively correlated with duration of hospitalisation $(p<0.001)$.

Conclusions: The presence of respiratory system diseases, especially pneumonia, was found to influence the incidence of DT in AWS patients. Increased clinical vigilance for the prevention of lower airway infections in AWS patients is essential.

Key words: respiratory system diseases, pneumonia, alcohol withdrawal syndrome, delirium tremens, somatic comorbidity.
\end{abstract}

\title{
Streszczenie
}

Cel: Celem badania była ocena wpływu poszczególnych grup chorób somatycznych i poszczególnych jednostek chorobowych somatycznych, a także wieku i płci pacjentów na wystąpienie epizodu majaczenia alkoholowego (łac. delirium tremens - DT) u pacjentów z alkoholowym zespołem abstynencyjnym (AZA). Przeanalizowano również wpływ wieku, płci i poszczególnych chorób somatycznych na długość hospitalizacji. Oceniono częstość współwystępowania chorób somatycznych wśród pacjentów leczonych z powodu AZA i DT.

Metody: Przeanalizowano dokumentację medyczną pacjentów przyjętych w 2019 r. na oddział leczenia alkoholowych zespołów abstynencyjnych jednego z polskich szpitali psychiatrycznych. Analizie poddano 800 hospitalizacji dotyczących 656 pacjentów (625 hospitalizacji z diagnozą AZA oraz 175 z diagnozą DT). 
Wyniki: Najczęstszą grupą chorób somatycznych wśród pacjentów z AZA i DT są choroby układu krążenia, a jednostką chorobową - nadciśnienie tętnicze pierwotne. Pacjenci z DT częściej mieli diagnozowane choroby układu oddechowego $(p<0,001)$ oraz zapalenie płuc $(p=0,000)$ niż pacjenci z AZA. Hospitalizacje trwały dłużej wśród pacjentów, u których stwierdzono zapalenie płuc, przewlekłą obturacyjną chorobę płuc, wrzody dwunastnicy, a krócej - u których stwierdzono zapalenie trzustki. Płeć i wiek pacjentów nie miały wpływu na rozwinięcie DT. Wiek pacjentów korelował dodatnio z długością hospitalizacji $(p<0,001)$.

Wnioski: Występowanie chorób układu oddechowego, a zwłaszcza zapalenia płuc, wpływa na rozwój DT u pacjentów leczonych z powodu AZA. Konieczna jest wzmożona czujność kliniczna w zakresie zapobiegania rozwojowi infekcji dolnych dróg oddechowych wśród pacjentów z AZA.

Słowa kluczowe: choroby układu oddechowego, zapalenie płuc, alkoholowy zespół abstynencyjny, majaczenie alkoholowe, współchorobowość somatyczna.

\section{INTRODUCTION}

Alcohol dependence syndrome (ADS) is a serious medical, social and economic problem in Poland and worldwide. According to the World Health Organization (WHO), alcohol abuse led to about 3 million deaths worldwide in 2016 [1]. WHO data for 2016 show that $2.2 \%$ of Poles $(4.1 \%$ of men and $0.4 \%$ of women) suffer from ADS. However, information on harmful consumption suggests that the problem of alcohol abuse is even more serious, as $12.8 \%$ of the Polish population $(22.7 \%$ of men and $3.7 \%$ of women) reported excessive alcohol consumption in 2016 [2]. While alcohol abuse is a common phenomenon across Europe, the frequency of ADS varies by country [3].

Protracted alcohol consumption, especially in large doses, may lead to alcohol withdrawal syndrome (AWS) after stopping alcohol consumption or reducing the amount. The course of AWS includes somatic symptoms, such as tremor of the upper extremities and tongue, increased perspiration, tachycardia, increased blood pressure, occasional grand mal type withdrawal seizures (approx. 3\% of persons affected by AWS [4]), nausea, vomiting, rapid breathing, higher body temperature and headaches. Other common symptoms include electrolytic imbalance and various mental states such as anxiety, irritability, fear, sleep disorders and psychomotor agitation [5-8]. AWS in its most severe form is life-threatening, especially if AWS patients develop delirium tremens (Latin: delirium tremens DT). If left untreated, DT has a mortality rate above $20 \%$, with some sources even suggesting approximately $40 \%$; however, with proper diagnostics and treatment the mortality rate is closer to $1 \%[4,9]$. DT is a state of mostly qualitative, often fluctuating consciousness disorders and problems with altered perceptions that frequently manifest as terrifying hallucinations - mainly visual ones, but also auditory - causing strong feelings of fear and anxiety, and occasional violence and self-aggression [6]. The neurobiological causes of DT may relate to the fact that persons abusing alcohol for extended periods of time display down-regulation of gamma amino butyric acid (GABA) receptors, which explains the positive effect of the administration of benzodiazepines as GABAergic treatment on the well-being of DT patients [6]. Understanding the reasons for DT symptoms in AWS patients is vital from a clinical viewpoint and holds an important place in the medical literature. Somatic states that may predispose a person to develop DT include high blood pressure [10], tremors and higher body temperature [12], thrombocytopenia, a high blood level of homocysteine [11], hypokalaemia, a low serum magnesium level, and advanced age [12], among others.

In Poland, AWS is mainly treated in psychiatric hospitals and the psychiatric wards of general hospitals, although affected patients may be admitted by any sector of the healthcare system - often hospital emergency units and emergency rooms. According to Marczuk et al. (2018), head trauma is the most frequent diagnosis for intoxicated patients treated in hospital emergency departments [13].

The goal of this study is to identify somatic diseases and groups (according to the WHO International Classification of Diseases, version 10 [ICD-10] criteria) related to a higher frequency of DT in AWS patients. We decided to additionally determine the prevalence of particular diseases (according to ICD-10), including groups of somatic diseases (also according to ICD-10) as well as the number of somatic diseases among patients dependent on alcohol that undergo AWS and DT treatment.

The specific relationships tested are as follows:

- the age and gender of hospitalised AWS patients with DT episodes;

- the correlation between patient age and duration of AWS and DT treatment in a psychiatric hospital;

- the association between patient gender and the presence of specific somatic diseases (according to the ICD-10 criteria) and the duration of AWS and DT treatment in a hospital;

- the link between the number of somatic diseases and the number of AWS and DT hospital treatments per year among patients hospitalised due to AWS or DT; and 
Somatic comorbidities of inpatients receiving treatment for alcohol withdrawal syndrome on a psychiatric ward and their relation to delirium tremens

Współchorobowość somatyczna pacjentów leczonych z powodu alkoholowego zespołu abstynencyjnego w szpitalu psychiatrycznym i jej związek z rozwojem majaczenia alkoholowego

- the association of particular somatic diseases and groups (according to the ICD-10 criteria) with the number ofAWS and DT treatmentsper year among patients with ADS.

\section{METHODS}

\section{Materials}

The research material comprised data gathered from the medical documentation archives of a psychiatric hospital in central Poland. The research was carried out with the written approval of the hospital management, followed all Polish and European regulations on personal data protection, and observed the Declaration of Helsinki (1964, as amended).

All medical documentation for patients age $\geq 18$ treated at the psychiatric hospital for AWS or DT in 2019 were reviewed. A total of 800 case histories were analysed, including 625 with an AWS diagnosis and 175 with a DT diagnosis. Hospitalisations concerned 656 persons, as some patients were hospitalised several times at the same hospital in the analysed year. 586 of the patients were hospitalized only once in the analysed year, 52 were hospitalized twice, 12 patients were hospitalized 3 times, 5 patients 4 times and only one patient was hospitalized 5 times. Persons with a simultaneous diagnosis of AWS and DT were excluded $(n=15)$. In addition, due to missing data, five hospitalisations of five patients $(n=5)$ were excluded. Thus, the AWS group included 506 persons (Females $[\mathrm{F}]=69,13.6 \%$ of all patients with AWS) age $45.51 \pm 11.83$ years (mean \pm standard deviation $[\mathrm{SD}]$ ), while the DT group included 150 persons $(\mathrm{F}=26,17.3 \%$ of all patients with DT ) age $46.19 \pm 12.57$ years. Diseases were classified according to the WHO ICD-10 criteria.

\section{Statistical analyses}

Statistical analyses were performed using IBM SPSS Statistics (version 26.0). Fisher's exact test was used to determine the relationship between nominal variables. The Mann-Whitney $U$ test was used to determine differences between the two groups. Differences between two qualitative variables were assessed using Spearman's rank correlation coefficient. To establish predictions, linear and logistic regression analysis using the introduction method was carried out. The level of statistical significance was set at $\alpha=0.05$.

\section{RESULTS}

\section{Analysed groups}

In the period analysed, a total of 625 AWS-related hospitalisations and 175 hospital stays due to DT diagnoses were noted. The average length of hospitalisation in the subgroup of patients with AWS was 10.5 days (SD $\pm 4.57)$ and in the subgroup of patients with DT it was 11.83 days ( $\mathrm{SD} \pm 6.13$ ). Hospitalisations of patients with DT diagnoses were significantly longer $(p=0.001)$ than those for patients with AWS.

\section{Occurrence of somatic diseases in alcohol dependence syndrome patients that underwent alcohol withdrawal syndrome and delirium tremens treatment in a psychiatric hospital}

While analysing data of patients undergoing AWS and DT treatment in a psychiatric hospital in 2019, it was concluded that the most common group of somatic diseases among ADS patients was circulatory system diseases, which affected $19.2 \%$ of AWS patients and $13.3 \%$ of DT patients. Among the various circulatory system diseases the most common was essential hypertension, which was diagnosed in $16.0 \%$ of AWS patients and $10.7 \%$ of DT patients. The second most common was atrial fibrillation, which was found in $1.8 \%$ of AWS patients and $3.3 \%$ of DT patients. The second most common group of diseases was disorders of internal secretion, nutrition and metabolism. Diabetes was most common, with insulin-independent diabetes diagnosed in $2.8 \%$ of patients and the administration of insulin considered essential for $1.8 \%$. For DT patients, the second most common group of diseases was respiratory tract diseases. Such diseases were confirmed in $8.7 \%$ of DT patients, with pneumonia being the most prevalent diagnosis $(4.7 \%)$. The third most common group of diseases in both subgroups was digestive tract diseases, which were found in $4.7 \%$ of AWS patients and DT patients. The frequency of somatic diseases and groups of somatic diseases (according to the ICD-10 classification) among ADS patients undergoing AWS or DT is shown in Table 1.

We also analysed the number of somatic diseases noted in the medical records of patients hospitalised due to AWS and DT. The majority of patients (69.8\% of AWS patients and $70.0 \%$ of DT patients) did not suffer from somatic diseases. $22.5 \%$ of patients with AWS and $22.0 \%$ of patients with DT had only one somatic disease. Two comorbid somatic diseases were diagnosed in $5.3 \%$ of patients with AWS and DT. $2.2 \%$ of AWS and $2.7 \%$ of DT patients suffered from three somatic diseases.

Next, we looked for the possible differences in the occurrence of somatic diseases in the patient subgroups related to gender or age. It should be noted that the results presented do not stem from longitudinal observations. The subgroups of patients (with AWS and DT) did not differ significantly with regard to current age and gender. The only statistically significant difference was for males in their sixth decade of age: Males aged 50-59 diagnosed with DT suffered from respiratory system diseases more frequently than those diagnosed with AWS. Detailed results of this analysis are presented in Table 2. 
Table 1. Frequency of somatic diseases (according to ICD-10) among patients that were hospitalised and underwent alcohol withdrawal syndrome (AWS) and delirium tremens (DT) treatment

\begin{tabular}{|c|c|c|c|c|}
\hline Factor & AWS, $n=506$ & DT, $n=150$ & $p$ & $\varphi / \mathrm{r}$ \\
\hline \multicolumn{5}{|l|}{ Certain infectious and parasitic diseases, $n(\%)$} \\
\hline Chronic viral hepatitis B & $0(0)$ & $0(0)$ & & \\
\hline Chronic viral hepatitis C & $1(0.2)$ & $0(0)$ & 1.000 & 0.02 \\
\hline Acute hepatitis B & $0(0)$ & $0(0)$ & & \\
\hline Acute hepatitis C & $0(0)$ & $0(0)$ & & \\
\hline Acute delta-(super)infection of hepatitis B carrier & $0(0)$ & $0(0)$ & & \\
\hline Human immunodeficiency virus (HIV) disease & $1(0.2)$ & $0(0)$ & 1.000 & 0.02 \\
\hline Diseases of circulatory system, $n(\%)$ & $97(19.2)$ & $20(13.3)$ & 0.115 & 0.06 \\
\hline Heart failure & $1(0.2)$ & $1(0.7)$ & 0.405 & 0.04 \\
\hline Oesophageal varices & $1(0.2)$ & $0(0)$ & 1.000 & 0.02 \\
\hline Ischaemic heart diseases & $5(1.0)$ & $1(0.7)$ & 1.000 & 0.01 \\
\hline Hypertensive diseases & $81(16.0)$ & $16(10.7)$ & 0.117 & 0.06 \\
\hline Atrial fibrillation & $9(1.8)$ & $5(3.3)$ & 0.330 & 0.05 \\
\hline Endocrine nutritional diseases and metabolic, $n$ (\%) & $29(5.7)$ & $3(2.0)$ & 0.082 & 0.07 \\
\hline Disorders of lipoprotein metabolism and other lipidaemias, $n$ (\%) & $3(0.6)$ & $0(0)$ & 1.000 & 0.04 \\
\hline Diabetes mellitus type I, n (\%) & $9(1.8)$ & $0(0)$ & 0.222 & 0.06 \\
\hline Diabetes mellitus type II, $n$ (\%) & $14(2.8)$ & $3(2.0)$ & 0.774 & 0.02 \\
\hline Diabetes mellitus type I or II, $n$ (\%) & $23(4.5)$ & $4(2.7)$ & 0.481 & 0.04 \\
\hline Hypothyroidism, n (\%) & $2(0.4)$ & $0(0)$ & 1.000 & 0.03 \\
\hline Hyperthyroidism, $n$ (\%) & $0(0)$ & $0(0)$ & & \\
\hline Digestive system diseases, $n$ (\%) & $24(4.7)$ & $7(4.7)$ & 1.000 & $<0.01$ \\
\hline Gastric ulcer & $0(0)$ & $0(0)$ & & \\
\hline Duodenal ulcer & $0(0)$ & $1(0.7)$ & 0.239 & 0.07 \\
\hline Peptic ulcer, site unspecified & $0(0)$ & $0(0)$ & & \\
\hline Gastrojejunal ulcer & $0(0)$ & $0(0)$ & & \\
\hline Gastritis and duodenitis & $2(0.4)$ & $0(0)$ & 1.000 & 0.03 \\
\hline Alcoholic liver disease & $17(3.4)$ & $5(3.3)$ & 1.000 & 0.01 \\
\hline Alcoholic cirrhosis & $2(0.4)$ & $1(0.7)$ & 0.542 & 0.02 \\
\hline Toxic liver disease & $0(0)$ & $0(0)$ & & \\
\hline Fibrosis and cirrhosis of liver & $0(0)$ & $0(0)$ & & \\
\hline Acute pancreatitis & $2(0.4)$ & $1(0.7)$ & 0.542 & 0.02 \\
\hline Chronic pancreatitis & $2(0.4)$ & $0(0)$ & 1.000 & 0.03 \\
\hline Crohn disease & $1(0.2)$ & $0(0)$ & 1.000 & 0.02 \\
\hline Ulcerative disease & $0(0)$ & $0(0)$ & & \\
\hline Respiratory system diseases, $n(\%)$ & $7(1.4)$ & $13(8.7)$ & $<0.001$ & 0.18 \\
\hline Pneumonia, organism unspecified & $2(0.4)$ & $7(4.7)$ & 0.001 & 0.15 \\
\hline Bacterial pneumonia & $0(0)$ & $0(0)$ & & \\
\hline Viral pneumonia & $0(0)$ & $0(0)$ & & \\
\hline Pneumonia due to Streptococcus pneumoniae & $0(0)$ & $0(0)$ & & \\
\hline Pneumonia due to Haemophilus influenza & $0(0)$ & $0(0)$ & & \\
\hline Pneumonia due to other infectious organisms, not elsewhere classified & $0(0)$ & $0(0)$ & & \\
\hline Chronic obstructive pulmonary disease & $3(0.6)$ & $1(0.7)$ & 1.000 & $<0.01$ \\
\hline Asthma & $1(0.2)$ & $2(1.3)$ & 0.133 & 0.07 \\
\hline Diseases of nervous system, $n(\%)$ & $8(1.6)$ & $5(3.3)$ & 0.186 & 0.05 \\
\hline Epilepsy & $5(1.0)$ & $3(2.0)$ & 0.392 & 0.04 \\
\hline Alcoholic polyneuropathy & $2(0.4)$ & $2(1.3)$ & 0.226 & 0.05 \\
\hline
\end{tabular}


Somatic comorbidities of inpatients receiving treatment for alcohol withdrawal syndrome on a psychiatric ward and their relation to delirium tremens

Współchorobowość somatyczna pacjentów leczonych z powodu alkoholowego zespołu abstynencyjnego w szpitalu psychiatrycznym i jej zwiq̨zek z rozwojem majaczenia alkoholowego

Table 1. Cont.

\begin{tabular}{|c|c|c|c|c|}
\hline Factor & AWS, $n=506$ & DT, $n=150$ & $p$ & $\varphi / \mathrm{r}$ \\
\hline \multicolumn{5}{|l|}{ Others, $n$ (\%) } \\
\hline Urinary infection & $3(0.6)$ & $0(0)$ & 1.000 & 0.04 \\
\hline Glaucoma & $1(0.2)$ & $0(0)$ & 1.000 & 0.02 \\
\hline
\end{tabular}

ICD-10 - International Classification of Diseases $10^{\text {th }}$ edition. Statistically significant results $(p<0.05)$ are bolded, $\varphi / r-$ effect size.

Table 2. Analysis of the frequency of somatic diseases among patients with alcohol dependence syndrome (ADS) undergoing treatment because of alcohol withdrawal syndrome (AWS) and delirium tremens (DT) with regard to age and gender

\begin{tabular}{|c|c|c|c|c|c|c|c|c|}
\hline \multirow[t]{2}{*}{ Factor } & \multicolumn{2}{|c|}{ Women } & \multirow[t]{2}{*}{$p$} & \multirow[t]{2}{*}{$\varphi$} & \multicolumn{2}{|c|}{ Men } & \multirow[t]{2}{*}{$p$} & \multirow[t]{2}{*}{$\varphi$} \\
\hline & AWS & DT & & & AWS & DT & & \\
\hline \multicolumn{9}{|c|}{ Circulatory system diseases, $n$ (\%) } \\
\hline $20-29$ y/o & $1(16.7)$ & $0(0)$ & 1.000 & 0.22 & $1(2.9)$ & $0(0)$ & 1.000 & 0.08 \\
\hline $30-39$ y/o & $0(0)$ & $1(20.0)$ & 0.250 & 0.40 & $13(115)$ & $1(3.0)$ & 0.192 & 0.12 \\
\hline $40-49$ y/o & $4(14.3)$ & $2(33.3 \%)$ & 0.281 & 0.19 & $18(13.1)$ & $4(11.1)$ & 0.791 & 0.03 \\
\hline $50-59$ y/o & $1(11.1)$ & $1(12.5)$ & 1.000 & 0.02 & $27(31.0)$ & $3(12.0)$ & 0.115 & 0.16 \\
\hline $60-69$ y/o & $4(40.0)$ & $3(60.0)$ & 0.608 & 0.19 & $24(42.9)$ & $4(22.2)$ & 0.164 & 0.18 \\
\hline $70 \mathrm{y} / \mathrm{o}$ and above & - & - & - & - & $4(40.0)$ & $1(25.0)$ & 1.000 & 0.14 \\
\hline \multicolumn{9}{|c|}{ Endocrine, nutritional and metabolic diseases, $n(\%)$} \\
\hline $20-29$ y/o & - & - & - & - & $2(5.9)$ & $0(0)$ & 1.000 & 0.12 \\
\hline $30-39$ y/o & - & - & - & - & $4(3.5)$ & $0(0)$ & 0.575 & 0.09 \\
\hline $40-49$ y/o & $1(3.6)$ & $0(0)$ & 1.000 & 0.08 & $3(2.2)$ & $1(2.8)$ & 1.000 & 0.02 \\
\hline $50-59$ y/o & $1(11.1)$ & $0(0)$ & 1.000 & 0.24 & $8(9.2)$ & $0(0)$ & 0.200 & 0.14 \\
\hline $60-69$ y/o & $2(20.0)$ & $0(0)$ & 0.524 & 0.28 & $6(10.7)$ & $1(5.6)$ & 1.000 & 0.08 \\
\hline $70 \mathrm{y} / \mathrm{o}$ and above & - & - & - & - & $2(20.0)$ & $1(25.0)$ & 1.000 & 0.06 \\
\hline \multicolumn{9}{|c|}{ Digestive system diseases, $n$ (\%) } \\
\hline $20-29$ y/o & - & - & - & - & - & - & - & - \\
\hline $30-39$ y/o & - & - & - & - & $6(5.3)$ & $5(15.2)$ & 0.125 & 0.16 \\
\hline $40-49$ y/o & - & - & - & - & $9(6.6)$ & $1(2.8)$ & 0.690 & 0.07 \\
\hline $50-59$ y/o & - & - & - & - & $7(8.0)$ & $0(0)$ & 0.341 & 0.13 \\
\hline $60-69$ y/o & - & - & - & - & $2(3.6)$ & $1(5.6)$ & 1.000 & 0.04 \\
\hline $70 \mathrm{y} / \mathrm{o}$ and above & - & - & - & - & - & - & - & - \\
\hline \multicolumn{9}{|c|}{ Respiratory system diseases, $n$ (\%) } \\
\hline $20-29$ y/o & - & - & - & - & - & - & - & - \\
\hline $30-39$ y/o & - & - & - & - & - & - & - & - \\
\hline $40-49$ y/o & $2(7.1)$ & $1(16.7)$ & 0.453 & 0.13 & $1(0.7)$ & $1(2.8)$ & 0.374 & 0.08 \\
\hline $50-59$ y/o & $0(0)$ & $1(12.5)$ & 0.471 & 0.27 & $1(1.1)$ & $4(17.4)$ & 0.007 & 0.32 \\
\hline $60-69$ y/o & $1(10.0)$ & $2(40.0)$ & 0.242 & 0.35 & $2(3.6)$ & $3(16.7)$ & 0.089 & 0.22 \\
\hline $70 \mathrm{y} / \mathrm{o}$ and above & - & - & - & - & $0(0)$ & $1(25.0)$ & 0.286 & 0.44 \\
\hline \multicolumn{9}{|c|}{ Diseases of nervous system, $n(\%)$} \\
\hline $20-29$ y/o & - & - & - & - & $1(2.9)$ & $0(0)$ & 1.000 & 0.08 \\
\hline $30-39$ y/o & - & - & - & - & $1(0.9)$ & $2(6.1)$ & 0.128 & 0.15 \\
\hline $40-49$ y/o & $1(3.6)$ & $0(0)$ & 1.000 & 0.08 & $3(2.2)$ & $0(0)$ & 1.000 & 0.07 \\
\hline $50-59$ y/o & - & - & - & - & $1(1.1)$ & $2(8.7)$ & 0.110 & 0.19 \\
\hline $60-69$ y/o & $1(10.0)$ & $0(0)$ & 1.000 & 0.19 & $0(0)$ & $1(5.6)$ & 0.243 & 0.21 \\
\hline $70 \mathrm{y} / \mathrm{o}$ and above & - & - & - & - & - & - & - & - \\
\hline
\end{tabular}

Statistically significant results $(p<0.05)$ are bolded, $\varphi$ - effect size. 
The assessment of the influence of somatic diseases on delirium tremens in persons with alcohol dependence syndrome hospitalised in a psychiatric hospital because of alcohol withdrawal syndrome diagnosis

A logistic regression analysis was performed for disease groups (according to the ICD-10 classification). The applied model was well-selected (Hosmer-Lemeshow test results: $\left.\chi^{2}(2)=0.69, p=0.708\right)$ and explained about $3 \%$ of variation in group classifications. The occurrence of respiratory system diseases was associated with nearly six-fold (odds ratio $(\mathrm{OR})=5.93$ ) more frequent DT development. Next, logistic regression analyses using the introduction method were performed for all AWS and DT hospitalisations to examine what diseases increased the risk of DT (patients who stayed in the hospital several times had each hospitalisation recorded separately; this allowed for the analysis to consider diseases of an acute nature, e.g., infections, surgeries, etc.). The model considered all diseases that occurred at least four times. The applied model turned out to be well-selected (Ho-
smer-Lemeshow test results: $\left.\chi^{2}(2)=1.14, p=0.768\right)$ and explained about $3 \%$ of variation in group classifications. It was concluded that pneumonia (J18 acc. to ICD-10) was related eleven times more to DT cases. However, none of the analysed circulatory system diseases, chronic obstructive pulmonary diseases (COPD), asthma, or acute pancreatitis were related to the frequency of DT diagnoses in ADS patients undergoing treatment. The results of the logistic regression analyses are presented in Table 3.

\section{Assessment of delirium tremens frequency depending on the age and gender of patients with alcohol dependence syndrome undergoing alcohol withdrawal syndrome treatment in a psychiatric hospital}

To determine whether patient age or gender was related to the occurrence of DT, linear regression analysis was performed. The applied model turned out to be well-selected (Hosmer-Lemeshow test results: $\left.\chi^{2}(8)=5.12, p=0.744\right)$ and explained less than $1 \%$ of va-

Table 3. Presence of diseases from groups of diseases and particular diseases (according to ICD-10) and the development of delirium tremens (DT) in patients with alcohol dependence syndrome (ADS) undergoing alcohol withdrawal syndrome (AWS) treatment in a psychiatric hospital

\begin{tabular}{|c|c|c|c|c|c|c|c|}
\hline \multirow[t]{2}{*}{ Factor } & \multirow[t]{2}{*}{ B } & \multirow[t]{2}{*}{ SE } & \multirow[t]{2}{*}{$z(1)$} & \multirow[t]{2}{*}{$p$} & \multirow[t]{2}{*}{ OR } & \multicolumn{2}{|c|}{$95 \% \mathrm{Cl}$ for OR } \\
\hline & & & & & & LL & UL \\
\hline \multicolumn{8}{|l|}{ Groups of diseases } \\
\hline Constant & -1.27 & 0.10 & 167.56 & $<0.001$ & 0.28 & & \\
\hline Disease of circulatory system & -0.28 & 0.25 & 1.33 & 0.250 & 0.75 & 0.46 & 0.46 \\
\hline Internal secretion system disorders & -1.04 & 0.62 & 2.76 & 0.097 & 0.36 & 0.11 & 0.11 \\
\hline Digestive system diseases & -0.16 & 0.44 & 0.14 & 0.712 & 0.85 & 0.36 & 0.36 \\
\hline Respiratory system diseases & 1.78 & 0.44 & 16.13 & $<0.001$ & 5.93 & 2.49 & 2.49 \\
\hline Nervous system diseases & 0.56 & 0.60 & 0.88 & 0.349 & 1.76 & 0.54 & 0.54 \\
\hline \multicolumn{8}{|l|}{ Diseases } \\
\hline Constant & -1.26 & 0.10 & 169.89 & 0.000 & 0.28 & & \\
\hline Heart failure & 0.39 & 1.28 & 0.09 & 0.759 & 1.48 & 0.12 & 18.00 \\
\hline Ischaemic heart diseases & -0.37 & 1.10 & 0.11 & 0.736 & 0.69 & 0.08 & 5.99 \\
\hline Hypertensive diseases & -0.33 & 0.27 & 1.55 & 0.213 & 0.72 & 0.43 & 1.21 \\
\hline Atrial fibrillation & 0.46 & 0.59 & 0.60 & 0.441 & 1.58 & 0.49 & 5.06 \\
\hline Diabetes mellitus & -0.78 & 0.62 & 1.59 & 0.208 & 0.46 & 0.14 & 1.55 \\
\hline Alcoholic liver disease & -0.26 & 0.53 & 0.23 & 0.630 & 0.77 & 0.27 & 2.20 \\
\hline Alcoholic cirrhosis & 0.76 & 1.37 & 0.31 & 0.576 & 2.15 & 0.15 & 31.27 \\
\hline Acute pancreatitis & 0.57 & 1.23 & 0.21 & 0.645 & 1.76 & 0.16 & 19.56 \\
\hline Pneumonia, organism unspecified & 2.48 & 0.70 & 12.58 & 0.000 & 11.89 & 3.03 & 46.70 \\
\hline Chronic obstructive pulmonary disease & -0.07 & 1.12 & 0.00 & 0.953 & 0.94 & 0.10 & 8.46 \\
\hline Asthma & 2.07 & 1.23 & 2.81 & 0.094 & 7.89 & 0.70 & 88.51 \\
\hline Epilepsy & 0.46 & 0.76 & 0.37 & 0.545 & 1.59 & 0.36 & 7.09 \\
\hline Alcoholic polyneuropathy & 0.68 & 1.14 & 0.35 & 0.553 & 1.97 & 0.21 & 18.56 \\
\hline
\end{tabular}

ICD-10 - International Classification of Diseases $10^{\text {th }}$ edition. Statistically significant results $(p<0.05)$ are bolded.

$L L$ - lower limit of the confidence interval, UL - upper limit of the confidence interval. 
Somatic comorbidities of inpatients receiving treatment for alcohol withdrawal syndrome on a psychiatric ward and their relation to delirium tremens

Współchorobowość somatyczna pacjentów leczonych z powodu alkoholowego zespołu abstynencyjnego w szpitalu psychiatrycznym i jej związek z rozwojem majaczenia alkoholowego

Table 4. Age and gender of patients with alcohol dependence syndrome (ADS) undergoing alcohol withdrawal syndrome (AWS) and delirium tremens (DT) treatment in a psychiatric hospital and the length of hospitalization

\begin{tabular}{|c|c|c|c|c|c|c|c|}
\hline \multirow[t]{2}{*}{ Factor } & \multirow[t]{2}{*}{ B } & \multirow[t]{2}{*}{ SE } & \multirow[t]{2}{*}{ Beta } & \multirow[t]{2}{*}{$t$} & \multirow[t]{2}{*}{$p$} & \multicolumn{2}{|c|}{$95 \% \mathrm{Cl}$ for $\mathrm{B}$} \\
\hline & & & & & & LL & UL \\
\hline (Constant) & 7.87 & 0.45 & & 17.44 & $<0.001$ & 6.98 & 8.75 \\
\hline Gender & 0.25 & 0.28 & 0.03 & 0.89 & 0.372 & -0.30 & 0.81 \\
\hline Age & 0.05 & 0.01 & 0.24 & 6.36 & $<0.001$ & 0.04 & 0.07 \\
\hline
\end{tabular}

Statistically significant results $(p<0.05)$ are bolded.

$L L$ - lower limit of the confidence interval, UL - upper limit of the confidence interval.

riation in the dependent variable (Cox and Snell's pseudo $\left.R^{2}=0.002\right)$. The analysis of all AWS-related hospitalisations showed that neither age $(p=0.314)$ nor gender $(p=0.46)$ was a significant predictor of DT.

\section{Length of alcohol withdrawal syndrome and delirium tremens hospital treatment of patients with alcohol dependence syndrome in relation to age, gender and specific diseases}

On the basis of all hospitalisations needed for AWS and DT treatment registered in 2019 at the hospital, the authors conducted a linear regression analysis to see whether the age and gender of patients were related to the length of their hospital stay. The analysis did not include extreme hospitalisations (above 3SD and patients discharged within 24 hours). The applied model was wellselected for the dataset $(\mathrm{F}(2.742)=20.51, p=0.001)$ and explained approximately $5 \%$ of variation in the dependent variable. The results showed that the length of hospital stay increased by a unit of 0.05 with each additional year of age. It was also determined that patient gender was not related to duration of hospital stay for AWS or DT treatment. Detailed results are presented in Table 4.

The association between specific diseases and length of hospital stay was also investigated by linear regression analysis using the introduction method (using the same dataset so as not to exclude acute diseases). The applied model was well-selected for the dataset $(\mathrm{F}(24.729)=3.41$, $p<0.001$ ). The analysis revealed that pneumonia (ICD10 category J18), COPD (ICD-10 category J44) and duodenal ulcer (ICD-10 category K26) were associated with a hospital stay that was longer by about 6 days. For patients with acute pancreatitis, their hospitalisation was significantly shorter by about 3 days compared to patients without such a diagnosis. Next, the linear regression analysis was conducted for disease groups (according to ICD-10 classifications). The applied model was well-selected for the dataset $(\mathrm{F}(5.3737)=6.60, p<0.001)$ and explained about $4 \%$ of variation $\left(R^{2}=0.036\right)$. The analysis showed that patients with diagnosed respiratory system diseases were hospitalised significantly longer by about 3 days compared to other patients. Detailed results are presented in Table 5.

\section{Assessment of the influence of diseases on the number of alcohol withdrawal syndromes (alcohol withdrawal syndrome and delirium tremens) per year that require alcohol withdrawal syndrome and delirium tremens treatment in a psychiatric hospital}

Next, we examined the question of whether any disease or group of diseases (according to ICD-10 classifications) was related to the number of AWS and DT cases that required treatment in a psychiatric hospital. This analysis was possible because of the region-specific psychiatric treatments applied de facto in the province (voivodeship) of Poland in which this study was conducted. First, ADS patients undergoing treatment were divided into two groups: those that underwent AWS and DT treatment in the hospital only once in the study period (586 persons) and those hospitalised more than once (70 persons). The analysis only considered diseases diagnosed in at least four patients. The ordinal regression analysis revealed that none of the diseases included was associated with an increase in hospitalisations per year.

There was also the question of whether any group of somatic diseases (according to ICD-10 classifications) was related to an increase or decrease in hospital stay caused by AWS or DT per year at the studied hospital. The results of the ordinal regression analysis did not identify any significant relationships.

\section{DISCUSSION}

This study of ADS patients undergoing treatment for AWS or DT at a psychiatric hospital in Poland revealed that the most common group of somatic diseases in such patients is circulatory system diseases (present in $19.2 \%$ of AWS patients and $13.3 \%$ of those with DT), with the most common condition being essential hypertension (diagnosed in 16\% of AWS patients and $10.7 \%$ of those with DT). The majority of patients in this study did not have a somatic disease diagnosis $(69.8 \%$ of AWS patients and 70\% of DT patients). However, men aged 50-59 diagnosed with DT suffered from respiratory tract diseases more often than men of the same age with an AWS diagnosis. When examining the association of somatic dise- 
Table 5. The occurrence of particular somatic diseases and groups of diseases (according to ICD-10) and the length of hospitalisation of patients with alcohol dependence syndrome (ADS) undergoing treatment in a psychiatric hospital due to alcohol withdrawal syndrome (AWS) and delirium tremens (DT)

\begin{tabular}{|c|c|c|c|c|c|c|c|}
\hline \multirow[t]{2}{*}{ Factor } & \multirow[t]{2}{*}{ B } & \multirow[t]{2}{*}{ SE } & \multirow[t]{2}{*}{$\boldsymbol{\beta}$} & \multirow[t]{2}{*}{$t$} & \multirow[t]{2}{*}{$p$} & \multicolumn{2}{|c|}{$95 \% \mathrm{Cl}$ for $\mathrm{B}$} \\
\hline & & & & & & LL & UL \\
\hline \multicolumn{8}{|l|}{ Diseases } \\
\hline Constant & 10.14 & 0.11 & & 89.61 & 0.000 & 9.92 & 10.37 \\
\hline Chronic viral hepatitis C & 2.86 & 2.72 & 0.04 & 1.05 & 0.294 & -2.48 & 8.20 \\
\hline Human immunodeficiency virus (HIV) disease & -0.14 & 2.72 & 0.00 & -0.05 & 0.958 & -5.48 & 5.20 \\
\hline Heart failure & 0.85 & 1.46 & 0.02 & 0.58 & 0.560 & -2.02 & 3.72 \\
\hline Oesophageal varices & 0.03 & 3.89 & 0.00 & 0.01 & 0.993 & -7.61 & 7.67 \\
\hline Ischaemic heart diseases & 1.84 & 1.12 & 0.06 & 1.64 & 0.101 & -0.36 & 4.04 \\
\hline Hypertensive diseases & 0.39 & 0.28 & 0.05 & 1.36 & 0.176 & -0.17 & 0.94 \\
\hline Atrial fibrillation & -0.27 & 0.75 & -0.01 & -0.37 & 0.715 & -1.74 & 1.20 \\
\hline Disorders of lipoprotein metabolism and other lipidaemias & 0.27 & 1.58 & 0.01 & 0.17 & 0.866 & -2.84 & 3.37 \\
\hline Diabetes mellitus type 1 and 2 & -0.76 & 0.57 & -0.05 & -1.34 & 0.182 & -1.89 & 0.36 \\
\hline Hypothyroidism & 2.36 & 1.93 & 0.04 & 1.22 & 0.221 & -1.42 & 6.14 \\
\hline Duodenal ulcer & 5.86 & 2.72 & 0.08 & 2.15 & 0.032 & 0.52 & 11.20 \\
\hline Gastritis and duodenitis & 2.86 & 2.72 & 0.05 & 1.05 & 0.294 & -2.48 & 8.20 \\
\hline Alcoholic liver disease & -0.03 & 0.61 & 0.00 & -0.06 & 0.956 & -1.23 & 1.16 \\
\hline Alcoholic cirrhosis & 0.52 & 1.70 & 0.01 & 0.31 & 0.760 & -2.81 & 3.85 \\
\hline Acute pancreatitis & -3.14 & 1.57 & -0.07 & -2.00 & 0.046 & -6.23 & -0.05 \\
\hline Chronic pancreatitis & 0.36 & 1.93 & 0.01 & 0.19 & 0.853 & -3.42 & 4.14 \\
\hline Crohn disease & -0.14 & 2.72 & 0.00 & -0.05 & 0.958 & -5.48 & 5.20 \\
\hline Glaucoma & 2.14 & 3.25 & 0.03 & 0.66 & 0.511 & -4.24 & 8.52 \\
\hline Pneumonia, organism unspecified & 5.63 & 1.00 & 0.21 & 5.63 & $<0.001$ & 3.67 & 7.60 \\
\hline Chronic obstructive pulmonary disease & 6.36 & 1.36 & 0.16 & 4.66 & $<0.001$ & 3.68 & 9.04 \\
\hline Asthma & -0.60 & 1.57 & -0.01 & -0.38 & 0.701 & -3.69 & 2.49 \\
\hline Epilepsy & -0.07 & 0.94 & 0.00 & -0.07 & 0.943 & -1.90 & 1.77 \\
\hline Alcoholic polyneuropathy & 1.99 & 1.62 & 0.05 & 1.23 & 0.220 & -1.19 & 5.17 \\
\hline Urinary tract infection & -2.68 & 1.58 & -0.06 & -1.70 & 0.090 & -5.79 & 0.42 \\
\hline \multicolumn{8}{|l|}{ Groups of diseases } \\
\hline Constant & 10.29 & 0.11 & - & 95.58 & 0.000 & 10.08 & 10.50 \\
\hline Diseases of circulatory system & 0.14 & 0.25 & 0.02 & 0.57 & 0.570 & -0.35 & 0.63 \\
\hline Endocrine nutritional diseases and metabolic & -0.59 & 0.47 & -0.05 & -1.25 & 0.212 & -1.52 & 0.34 \\
\hline Digestive system diseases & 0.33 & 0.46 & 0.03 & 0.71 & 0.476 & -0.58 & 1.23 \\
\hline Respiratory system diseases & 3.31 & 0.66 & 0.18 & 5.04 & 0.000 & 2.02 & 4.59 \\
\hline Diseases of nervous system & 1.23 & 0.73 & 0.06 & 1.69 & 0.092 & -0.20 & 2.66 \\
\hline
\end{tabular}

Statistically significant results $(p<0.05)$ are bolded. $L L$ - lower limit of the confidence interval, UL - upper limit of the confidence interval.

ases with DT, it was noted that DT patients suffered from respiratory tract diseases and pneumonia (J18 according to ICD-10) significantly more often than AWS patients $(p<0.000)$. The analysis also allowed for the conclusion that the age and gender of patients were not related to the frequency of DT symptoms. The dataset showed that the length of hospital stay increased significantly with patient age. Somatic diseases also affected the duration of hospitalisation. Acute pancreatitis patients were hospitalised for a significantly shorter period of time than other patients (by approximately 3 days), while patients with COPD and duodenal ulcers were hospitalised significantly longer than other patients (by approximately 6 days). It was also found that none of the diseases or groups of diseases were related to the number of hospitalisations per year for AWS or DT treatment. 
These findings highlight the important role of somatic factors in DT development in patients with AWS, which is consistent with previous studies. In a study from Germany, the risk factors for developing DT in AWS patients were (among others) hypokalaemia and the presence of brain lesions [14].

A Spanish cohort study by Monte et al. revealed that AWS-treated patients with seizures, a body temperature above $38^{\circ} \mathrm{C}$ measured in the armpit, and a systolic blood pressure above $150 \mathrm{mmHg}$ were at a higher risk of developing DT [10]. Another study pointed to frequent thrombocytopenia in patients with severe AWS, along with complications in the form of alcoholic seizures or DT [15]. A study conducted by Polish researchers reported a relation between the occurrence of thrombocytopenia and higher risk of developing complicated AWS (with DT or withdrawal seizures) in a population of Polish patients with AWS. The researchers reported that the highest risk was when the platelet level was below $119 \mathrm{k} / \mathrm{ml}$ [16]. Palmstierna (2001) identified five factors that may predict DT in patients admitted to hospitals: tachycardia, symptoms of infection, signs of AWS with a concentration of alcohol in body fluids above $1 \mathrm{~g} / \mathrm{l}$, epileptic fits and DT episodes in the medical history [17]. Teetharatkul et al. (2018) pointed to red blood count cells lower than $4.5 \times 10^{6} / \mu \mathrm{l}$ as a significant risk factor of delirium tremens [18]. According to Benson et al. (2019), among others, the value of systolic blood pressure is associated with the development of DT or withdrawal seizures [19]. Another study indicated a role of serum alanine aminotransferase level and initial patient management in the development of severe AWS [20]. A meta-analysis by Goodson et al. (2014) pointed to hypokalaemia, thrombocytopenia and, most importantly, severe AWS in the medical history (with DT and/or seizures) as risk factors for developing severe AWS. The authors highlight the need to obtain deeper insights into the issue [21]. In a review article, Silczuk and Habrat (2020) noted the increasing importance of thrombocytopenia among the parameters used to determine the risk of DT or withdrawal seizures [22]. In clinical practice, it is crucial to differentiate the somatic states of patients as it may help in assessing the risk of developing DT in those admitted to a hospital due to AWS. According to the present study, DT symptoms in the course of AWS were observed more often in patients with lung diseases, especially pneumonia. Acute infectious diseases are widely recognised as a potential risk factor for the development of DT in AWS patients [23]. In an interesting study by Gupta et al. (2019), it was shown that American patients with alcohol use disorder who suffered pneumonia were infected by drug resistant organisms less often than patients without alcohol use disorder. Among patients with alcohol use disorder, those with AWS had a higher risk of clinical deterioration [24]. In another study (de Roux et al., 2006), researchers noted that pneumococcal infec- tion occurred more often in patients with ADS and that actual ADS was associated with severe pneumonia [25].

A systematic review (Wood et al., 2018) pointed out that a single symptom is not helpful in assessing the risk of developing severe AWS (understood as the occurrence of alcoholic seizures, DT or clinical classification of severe AWS) and that diagnostic tools analysing combinations of many symptoms are more useful [26]. Kraemer et al. (2003) found that patients with three or more risk factors have a higher risk of developing severe AWS [27]. In searching for factors that may increase the risk of DT, patient gender has also been considered. However, in the present study this was not significantly related to a greater tendency to develop DT. A previous reported indicated that male gender, among others factors (Caucasian race, history of psychiatric disorders, thrombocytopenia, etc.), may increase the risk of developing benzodiazepine-resistant alcohol withdrawal (in this study specified as being when $40 \mathrm{mg}$ of diazepam or more needs to be administered in 1 hour) [28].

A Spanish study (Puerta Louro et al., 2006) noted advanced age as a factor related to higher mortality in AWS patients [29]. Our study did not find a connection between patient age and risk of developing DT, but did find a positive correlation between patient age and length of hospitalisation $(p<0.001)$.

The frequency of particular somatic diseases among patients in our study is also worth discussing. On the basis of medical records, the most frequent somatic disease diagnosed among ADS patients was essential hypertension - which was found in $16.0 \%$ of AWS patients and $10.7 \%$ of those with DT. However, the rates found here are much lower than those described for the general Polish population. According to NATPOL 2011, essential hypertension is diagnosed in $39.3 \%$ of Poles aged 40-59 [30]. Diabetes was diagnosed in $4.5 \%$ of AWS patients and $2.7 \%$ of DT patients included in this study, while IDF data suggest that diabetes affects approximately $8.1 \%$ of Poles aged 20-79 [31]. Over $60 \%$ of adult Poles suffer from hypercholesterolemia, while only $0.6 \%$ of the examined AWS patients and none of the DT patients displayed lipidaemia [32]. These data appear to be of interest in relation to a study (Mori et al., 2015) reporting that greater use of alcohol was associated with increased high-density lipoproteins (HDL) in serum [33].

The underestimated rates of somatic diseases among patients with ADS require further research. It also makes the elaboration of DT risks more difficult, especially since the results obtained contradict the findings of prior studies. ADS has been associated with a higher risk of somatic co-morbidities [6]. A Danish cohort study (Holst et al., 2017) revealed that persons with ADS are at a higher risk of developing somatic diseases compared to the control group [34]. An international European survey that was also carried out in Poland revealed that $34.8 \%$ of patients with ADS reported at least one somatic disease [35]. 
Patients with alcohol use disorder have a higher risk of ischemic heart disease mortality [36]. A meta-analysis (Briasoulis et al., 2012) showed that drinking larger amounts of alcohol raises the risk of hypertension in men and woman [37]. Similarly, a Danish prospective cohort study revealed that consuming more than 35 drinks per week is associated with an increased risk of atrial fibrillation in men [38]. Notably, $35 \%$ of people who abuse alcohol will develop a serious liver disease [39]. Alcohol abuse negatively affects liver functioning after 1-5 years [40]. In a study conducted in central Poland, $34.4 \%$ patients with ADS reported physical pain during the previous month [41]. The problem of underdiagnosing somatic diseases in patients in Polish psychiatric hospitals has been raised before [42].

Attention should also be paid to the fact that, in light of our dataset, some somatic diseases present in patients hospitalised in a psychiatric hospital for AWS or DT treatment were tied to a longer hospital stay. According to a study by Fabisiak et al. (2018), alcohol is the main aetiological factor of acute pancreatitis in patients admitted to a gastrointestinal ward [43]. This finding may explain the observation of a shorter hospitalisation stay by approximately 3 days in patients with AWS and acute pancreatitis (AP), since patients with AP require treatment in specialist hospitals. By contrast, longer hospitalisations were recorded for diseases such as pneumonia, COPD and duodenal ulcers. Future research should assess the influence of ulcers on the course of AWS and length of hospitalisation.

It is known that chronic peptic ulcer disease, Mallory -Weiss syndrome and Dieulafoy's lesion in alcoholic liver disease patients lead to increased bleeding in the upper parts of the digestive tract [44]. Thus, the longer hospital stays in patients with respiratory tract diseases may be explained by significantly more frequent DT episodes.

\section{LIMITATIONS}

This study is subject to several limitations. First, it was conducted at a single medical centre. Information on somatic diseases in patients' medical records was often provided by the patients themselves. Furthermore, patients' mental and somatic states during hospitalisation do not always allow for a complete medical interview regarding treatment history and an objective history from the patient's family is not always available. The attending physicians were not always able to access medical histories from primary healthcare records, specialist outpatient care or information sheets from specialist hospitals. In addition, this study did not include patients presenting at the hospital admission room who were not admitted to a psychiatric hospital due to insufficient intensity of AWS symptoms or too severe a general condition. In psychiatric hospitals, the ability to carry out full somatic diagnostics may be limited by the lack of advanced medical equipment or limited availability of specialist physicians other than psychiatrists and internists, such that some somatic diseases may not be included in the medical documentation and therefore not included in the analyses. Some of the analyses were conducted on the basis of the assumption that patients with AWS were hospitalised according to the region of their residence. However, this zoning is unofficial (although mostly respected) and does not include private medical centres.

\section{CONCLUSIONS}

The results of this study confirm the association between particular somatic diseases and the development of DT in AWS patients, as described in the prior literature. The questions posed throughout this study are practical in nature. Due to the high mortality rate of untreated DT, clinicians need to know the factors that may predispose a patient to develop DT. The investigation revealed that respiratory tract diseases, especially pneumonia, were associated with significantly more frequent DT symptoms in AWS patients, while patient age and gender showed no correlations with DT diagnoses. Therefore, clinicians should pay closer attention to prevention, early diagnostics and optimal treatment of respiratory system diseases. The most frequent somatic diseases among patients with ADS undergoing AWS and DT treatment were cardiovascular diseases and hypertension. However, compared to data for the general Polish population, the rates of somatic comorbidities seem low and thus suggest an underestimation of somatic diseases among ADS patients. The influence of somatic health on the development and course of DT thus requires further research.

\section{Acknowledgements/Podziękowania}

The authors would like to thank hospital management for agreeing to this research. We are also grateful to the reviewers, whose comments significantly improved this manuscript. 
Somatic comorbidities of inpatients receiving treatment for alcohol withdrawal syndrome on a psychiatric ward and their relation to delirium tremens

Wspótchorobowość somatyczna pacjentów leczonych z powodu alkoholowego zespołu abstynencyjnego w szpitalu psychiatrycznym i jej związek z rozwojem majaczenia alkoholowego

\section{Conflict of interest/Konflikt interesu}

Absent./Nie występuje.

Financial support/Finansowanie

Absent./Nie występuje.

\section{References/Piśmiennictwo}

1. World Health Organization. Global status report on alcohol and health 2018. Geneva: World Health Organization; 2018. https://www.who.int/publications/i/item/9789241565639 (Accessed: 13.02.2021).

2. WorldHealth Organization.https://www.who.int/substance_abuse/publications/global_alcohol_report/profiles/ pol.pdf?ua=1 (Accessed: 13.02.2021).

3. WorldHealth Organization.https://www.who.int/substance_abuse/publications/global_alcohol_report/profiles/ en/ (Accessed: 13.02.2021).

4. American Psychiatric Association. Practice guideline for the treatment of patients with substance use disorders, $2^{\text {nd }}$ ed. In: American Psychiatric Association Practice Guidelines for the Treatment of Psychiatric Disorders: Compendium 2006. Arlington, VA: American Psychiatric Association; 2006, p. 291-563. http://www.psych.org/ psych_pract/treatg/pg/SUD2ePG_04-28-06.pdf.

5. Mehta SR, Prabhu H, Swamy AJ, Dhaliwal H, Prasad D. Delirium tremens. Med J Armed Forces India 2004; 60: 25-27.

6. Grover S, Ghosh A. Delirium tremens: assessment and management. J Clin Exp Hepatol 2018; 8: 460-470.

7. Mayo-Smith MF, Beecher LH, Fischer TL; Working Group on the Management of Alcohol Withdrawal Delirium, Practice Guidelines Committee, American Society of Addiction Medicine. Management of alcohol withdrawal delirium. An evidence-based practice guideline. Arch Intern Med 2004; 164: 1405-1412.

8. American Psychiatric Association. Diagnostic and Statistical Manual of Mental Disorders, $4^{\text {th }}$ ed. Washington: American Psychiatric Association; 1994.

9. Blom J. A dictionary of hallucinations. $1^{\text {st }}$ ed. New York: Springer; 2010, p. 136.

10. Monte R, Rabuñal R, Casariego E, Bal M, Pértega S. Risk factors for delirium tremens in patients with alcohol withdrawal syndrome in a hospital setting. Eur J Intern Med 2009; 20: 690-694.

11. Kim DW, Kim HK, Bae EK, Park SH, Kim KK. Clinical predictors for delirium tremens in patients with alcohol withdrawal seizures. Am J Emerg Med 2015; 33: 701-704.

12. Schuckit MA. Recognition and management of withdrawal delirium (delirium tremens). N Engl J Med 2014; 371: 2109-2113.

13. Marczuk J, Pruc M, Wisniewska Z, Gawel W, Olszewski H, Szarpak $€$. The cost analysis and the assessment of intoxicated patients in the Emergency Unit of the Child Jesus Clinical Hospital in Warsaw in 2013. Post N Med 2018; 31: 188-194.

14. Eyer F, Schuster T, Felgenhauer N, Pfab R, Strubel T, Saugel B, Zilker T. Risk assessment of moderate to severe alcohol withdrawal - predictors for seizures and delirium tremens in the course of withdrawal. Alcohol Alcohol 2011; 46: 427-433.

15. Berggren U, Fahlke C, Berglund KJ, Blennow K, Zetterberg H, Balldin J. Thrombocytopenia in early alcohol withdrawal is associated with development of delirium tremens or seizures. Alcohol Alcohol 2009; 44: 382-386.

16. Silczuk A, Habrat B, Lew-Starowicz M. Thrombocytopenia in patients hospitalized for alcohol withdrawal syndrome and its associations to clinical complications. Alcohol Alcohol 2019; 54: 503-509.

17. Palmstierna T. A model for predicting alcohol withdrawal delirium. Psychiatr Serv 2001; 52: 820-823.

18. Teetharatkul T, Vittayanont A. Delirium tremens in psychiatric ward at Songklanagarind Hospital. J Health Sci Med Res 2018; 36: 205-214.

19. Benson G, McCallu J, Roberts NJ. Risk factors for severe alcohol withdrawal syndrome in an acute hospital population. J Addict Nurs 2019; 30: 159-168.

20. Mennecier D, Thomas M, Arvers P, Corberand D, Sinayoko L, Bonnefoy S, et al. Factors predictive of complicated or severe alcohol withdrawal in alcohol dependent inpatients. Gastroenterol Clin Biol 2008; 32: 792-797.

21. Goodson CM, Clark BJ, Douglas IS. Predictors of severe alcohol withdrawal syndrome: a systematic review and meta-analysis. Alcohol Clin Exp Res 2014; 38: 2664-2677.

22. Silczuk A, Habrat B. Alcohol-induced thrombocytopenia: current review. Alcohol 2020; 86: 9-16.

23. Thiercelin N, Rabiah Lechevallier Z, Rusch E, Plat A. Risk factors for delirium tremens: a literature review. Rev Med Interne 2012; 33: 18-22 [Article in French].

24. Gupta NM, Lindenauer PK, Yu PC, Imrey PB, Haessler S, Deshpande A, et al. Association between alcohol use disorders and outcomes of patients hospitalized with community-acquired pneumonia. JAMA Netw Open 2019; 2: e195172.

25. de Roux A, Cavalcanti M, Marcos MA, Garcia E, Ewig S, Mensa J, Torres A. Impact of alcohol abuse in the etiology and severity of community-acquired pneumonia. Chest 2006; 129: 1219-1225.

26. Wood E, Albarqouni L, Tkachuk S, Green CJ, Ahamad K, Nolan S, et al. Will this hospitalized patient develop severe alcohol withdrawal syndrome? The rational clinical examination systematic review. JAMA 2018; 320: 825-833.

27. Kraemer KL, Mayo-Smith MF, Calkins DR. Independent clinical correlates of severe alcohol withdrawal. Subst Abus 2003; 24: 197-209. 
28. Benedict NJ, Wong A, Cassidy E, Lohr BR, Pizon AF, Smithburger PL, et al. Predictors of resistant alcohol withdrawal (RAW): a retrospective case-control study. Drug Alcohol Depend 2018; 192: 303-308.

29. Puerta Louro R, Otero Antón E, Lorenzo Zúñiga V. Epidemiología del síndrome de abstinencia alcohólica: mortalidad y factores de mal pronóstico. Anales de Medicina Interna 2006; 23: 307-309.

30. Januszkiewicz A, Prejbisz A. Vadamecum diagnostyki i leczenia nadciśnienia tętniczego [Vadamecum of Diagnostics and Treatment of Hypertension]. Kraków: Medycyna Praktyczna; 2016.

31. International Diabetes Federation. IDF Diabetes Atlas, $9^{\text {th }}$ ed.; 2019. https://www.diabetesatlas.org.

32. Zdrojewski T, Solnica B, Cybulska B, Bandosz P, Rutkowski M, Stokwiszewski J, et al. Prevalence of lipid abnormalities in Poland. The NATPOL 2011 survey. Kardiol Pol 2016; 74: 213-223.

33. Mori TA, Burke V, Beilin LJ, Puddey IB. Randomized controlled intervention of the effects of alcohol on blood pressure in premenopausal women. Hypertension 2015; 66: 517-523.

34. Holst C, Tolstrup JS, Sørensen HJ, Becker U. Alcohol dependence and risk of somatic diseases and mortality: a cohort study in 19002 men and women attending alcohol treatment. Addiction 2017; 112: 1358-1366.

35. Rehm J, Allamani A, Aubin HJ, Della Vedova R, Elekes Z, Frick U, et al. People with alcohol use disorders in specialized care in eight different European countries. Alcohol Alcohol 2015; 50: 310-318.

36. Roerecke M, Rehm J. Chronic heavy drinking and ischaemic heart disease: a systematic review and meta-analysis. Open Heart 2014; 1: e000135.

37. Briasoulis A, Agarwal V, Messerli FH. Alcohol consumption and the risk of hypertension in men and women: a systematic review and meta-analysis. J Clin Hypertens (Greenwich) 2012; 14: 792-798.

38. Mukamal KJ, Tolstrup JS, Friberg J, Jensen G, Grønbaek M. Alcohol consumption and risk of atrial fibrillation in men and women: the Copenhagen City Heart Study. Circulation 2005; 112: 1736-1742.

39. Osna NA, Donohue TM Jr, Kharbanda KK. Alcoholic liver disease: pathogenesis and current management. Alcohol Res 2017; 38: 147-161.

40. Gazy P, Standowicz S, Marciniak S, Echolc B, Mazur B. The effect of chronic alcohol abuse on liver damage and function - analysis of basic biochemical and coagulological parameters. Alcohol Drug Addict 2019; 32: 101-108.

41. Jakubczyk A, Ilgen MA, Bohnert AS, Kopera M, Krasowska A, Klimkiewicz A, et al. Physical pain in alcoholdependent patients entering treatment in Poland - prevalence and correlates. J Stud Alcohol Drugs 2015; 76: 607-614.

42. Ring M, Berent D, Bieńkowski P. Potential underdiagnosis of somatic comorbidity in patients with schizophrenia and with bipolar disorder. Med Rodz 2020; 23: 99-108.

43. Fabisiak N, Fabisiak A, Małecka-Panas E. Gąsiorowska A. Acute pancreatitis - epidemiology, etiology, procedures and treatment: a retrospective cohort study. Post N Med 2018; 31(2A): 22-28.

44. Nojkov B, Cappell MS. Distinctive aspects of peptic ulcer disease, Dieulafoy's lesion, and Mallory-Weiss syndrome in patients with advanced alcoholic liver disease or cirrhosis. World J Gastroenterol 2016; 22: 446-466. 